\title{
Is 'decolonisation' a legitimate and appropriate value in biomedical research and teaching?
}

\author{
A A van Niekerk, BA Hons, BTh, LTh, MA, DPhil \\ Centre for Applied Ethics, Department of Philosophy, Faculty of Arts, Stellenbosch University, Cape Town, South Africa
}

Corresponding author: A A van Niekerk (aavn@sun.ac.za)

This article investigates the claim that decolonisation is an appropriate and legitimate value in the process of current-day biomedical research, particularly in Africa. Can we expect that the nature and effects of the decolonisation of research will be comparable and similar for all scientific disciplines (obviously including the biomedical disciplines), or does the claim to significant differences between the 'natural' and 'human' sciences have notable implications for our understanding of both the nature and the effects of decolonisation, as well as for our understanding of the biomedical disciplines themselves? In this article I firstly analyse the notion of decolonisation. Secondly, I investigate the legitimacy of holding and maintaining a conceptual difference between the natural and the human sciences. I do this in conversation with Charles Taylor and Jürgen Habermas, who have produced invaluable contributions in this regard. Thirdly, I apply these insights to the question as to whether the decolonialist project (the general legitimacy of which I accept) is equally applicable to both the natural and the human sciences in their traditional formats. Finally, I discuss the relevance of this debate for both the nature of the biomedical sciences and the question as to the extent to which the biomedical sciences can and ought to be successfully decolonised - a question that is answered in the affirmative.

S Afr J Bioethics Law 2019;12(1):4-7. DOI:10.7196/SAJBL.2019.v12i1.652

The 'decolonisation' of science and education broadly refers to the radical questioning, unmasking and undoing of the colonial context and values that permeated education and scientific training in the period when most countries in the so-called developing world (Africa in particular) were colonised and exploited by countries and/or institutions in the so-called developed world. It is a position recently summarised by Sarah Chiumbu ${ }^{[1]}$ as follows:

'The basic tenets of Western knowledge should not be seen as all good or bad, but we should recognise that they are historically situated and potentially restrictive if universalised through our projects, as they prevent the imagination of other possibilities.'

The decolonialist literature is already too broad for a simple overview. Much, in particular, has been written about the decolonisation of the (school and university) curriculum. This article is not about the decolonisation of the curriculum, but rather focuses on an aspect of the decolonisation of the university that has received less attention in the literature, namely the decolonisation of research, or the attainment of scientific knowledge, at the university.

Universities are institutions that are fundamentally defined by the scientific nature of the knowledge that they produce and disseminate. ${ }^{[2]}$ What does strike one in debates about the decolonisation of the research (or science acquisition) project is the undifferentiated way in which participants tend to talk or write about 'science'. Very little attention is, in these debates, paid to the question of whether there are any significant differences between the alleged 'natural' and 'social' (often also referred to as 'human') sciences, ${ }^{[3]}$ and what the implications of these differences for the decolonisation of research at the university might be.

The latter is the issue that I would like to address in this article. My question, in short, is: can we expect that the nature and effects of the decolonisation of research will be comparable and similar for all scientific disciplines (obviously including the biomedical disciplines), or does the claim to significant differences between the natural and social/human sciences have notable implications for our understanding of both the nature and the effects of decolonisation, and for our understanding of the biomedical disciplines themselves?

What I would therefore like to do, is the following: firstly, I will briefly expand on the tentative understanding and legitimacy of decolonisation that I provided at the beginning of this introduction. Secondly, I would like to briefly investigate the legitimacy of holding and maintaining a conceptual difference between the natural and the social/human sciences. I will do this in conversation with foremost hermeneutical thinkers such as Charles Taylor and Jürgen Habermas, who have, to my mind, produced invaluable contributions in this regard. Thirdly, I would like to apply these insights to the question of whether the decolonialist project (the general legitimacy of which I accept, as will become evident from the next section) is equally applicable to both the natural and the social sciences in their traditional formats. Finally, I will ask what the relevance of this debate is for understanding the nature of the biomedical sciences, and the question of the extent to which the biomedical sciences can be successfully decolonised.

\section{What is decolonisation?}

Decolonised science and research refers to the indigenisation of the scientific and educational enterprise in a postcolonial context. Decolonisation is often, specifically in the African context, closely associated with the desired 'Africanisation' of knowledge and research. It is a response to the claim that the centre of gravity 
in terms of which reliable and properly applicable knowledge is required and dispersed is Europe and/or North America.

One ought to be careful to simply equate decolonisation and Africanisation. Mbembe ${ }^{[4]}$ writes in this regard: 'Calls to "decolonise" are not new. Nor have they gone uncontested whenever they have been made. We all have in mind African postcolonial experiments in the 1960s and 1970s. Then, to "decolonise" was the same thing as "to Africanise."' He then refers to Fanon's critique of the (then) project of Africanisation, which Fanon regarded as no more than an excuse for the African middle class to acquire benefits that used to belong to the colonisers.

Mbembe is indeed right when he remarks that calls for decolonisation are not new in our time. They are particularly not new in so far as they emphasise the historical situatedness of scientific research. Although not related to decolonisation as such, in the course of the 20th century the insight into the situatedness of science and research was responsible for great upheavals in debates about the nature and history of science among the ranks of well-known Western philosophers of science. Particularly in the second half of the previous century, forefront post-empiricist philosophers and historians of science such as Thomas Kuhn, ${ }^{[5]}$ Imre Lakatos ${ }^{[6]}$ and Paul Feyerabend ${ }^{[7]}$ took the general critical reaction to positivism in the philosophy of science to unprecedented new levels.

This is not the time or place to deal with these debates and controversies. The simple point I would like to stress, though, is the fact that the situatedness of knowledge, and hence the expedience of knowledge for specific communities and (also political) projects is equally recognised by decolonialist and postempiricist philosophers of science. The idea that science has a uniform logic and that reality is under all circumstances objectively accessible and knowable in terms of the application of a universally valid methodological framework ${ }^{[8]}$ is one that has lost a great deal of credibility in our time. Both in European and in postcolonial thinking, there is increasing realisation of:

- the role of tradition and authority in the acquisition of knowledge

- theoretical frames of reference, transmitted historically, that condition the possibilities and even the contents of perceptions

- the role of language in the acquisition of science - language as the key to and medium of all forms of understanding

- the pivotal role of sociohistorical circumstances, influences, preferences and even prejudices, as well as personal and professional aspirations, in the generation of knowledge claims. ${ }^{[9]}$

\section{The distinction between natural and social sciences}

The ideas associated with a decolonised scientific/research practice are therefore not that new. The question remains as to whether they are valid. This article explores the extent to which sense can be made of the drive to decolonise research, given the nature of the scientific and research enterprise as it has unfolded historically, providing demonstrable truth claims, results and effects. How seriously can and must we take the idea that there is no standard scientific method if the latter is the implication of the decolonialist project? How easily can we relinquish the assumption of a standard methodological framework that is allegedly valid everywhere and for all?

In order to answer these questions, I wish to draw on some insights of the German philosopher Jürgen Habermas. In his book
Knowledge and Human Interests, ${ }^{[10]}$ Habermas argues forcefully in favour of the idea - widely shared by proponents of decolonisation - that knowledge acquisition is always driven by human interests. Secondly, he approaches the question of what the original purpose and end results of knowledge acquisition are from a fundamentally anthropological angle.

For Habermas, our most basic traits as a species spring from two original human activities, namely labour and communication. In turn, labour and communication as species-typical activities are the outcome of two fundamental interests that we adopt towards our world: the so-called technical and practical interests. ${ }^{[10]}$ Labour - the creative human impingement on our environment for the sake of bodily survival - is the activity that flows from the technical interest. By the latter, Habermas means the interest that all of us have in deciphering the regularities that govern our natural environment, in order to enable us to understand, predict and apply these regularities for the sake of our biological survival. This is what happens in sciencebased technologies. Put differently, the technical interest refers to a striving towards the attainment of control over the forces and processes in our natural environment - a control that enables us to survive biologically in this environment and to adapt or organise it optimally for our mutual benefit. The empirical-analytical sciences (by which Habermas means the natural and applied sciences) are the systematic formation of the execution of the technical interest. ${ }^{[10]}$

However, humankind is more than mere labourer. Man/woman does not realise his/her identity only on the basis of the technical interest. We, as a species, are human on another basis than merely that of labour and technology; we do not 'live of bread alone.' This other manner of existence is, for Habermas, communication, by which he means the search for meaning, which is the outcome of the second interest on the basis of which we produce culture. Habermas calls this second interest the practical interest, i.e. the interest that we all have, based on continuous intersubjective dialogue, in coming to a mutual understanding or consensus about the kind of life that is worth our while, and the values that ought to inform it. In view of this second ideal/interest, humankind creates symbolic forms (i.e. works of art, texts, artefacts, values, political systems, ideologies, etc.) that are expressions of the ways in which we, in deliberation and collaboration with fellow human beings, make sense of our world and ourselves.

For Habermas, the 'historical hermeneutical' (we could also say the social/human) sciences are the systematic formation of the practical interest, i.e. of the second, equally important and unavoidable way in which we are what we are and in which we realise our particular identity as a species. ${ }^{[10]}$

These historical hermeneutical or social sciences (such as economics, sociology and political science) could and often do produce nomological knowledge, of which scientific knowledge is the prototype. Habermas, however, also identifies a third interest from which knowledge - albeit a markedly different kind of knowledge springs. He calls it the emancipatory interest. This is the interest undergirding truly critical social sciences. This is the type of critical theory that often acts as the critique of ideology - an epistemic enterprise that identifies and transcends 'frozen relationships of dependence that can in principle be transformed!. ${ }^{[10]}$

Charles Taylor ${ }^{[11]}$ is another philosopher who insists on the 'disanalogy' between theory formation in the empirical-analytical v. critical-social 
sciences. The most important difference between them relates to the fact that, in the case of the social sciences, we normally have a commonsense understanding of what it is that we try to elucidate theoretically. To quote Taylor: 'There is always a pre-theoretical understanding of what is going on among the members of a society, which is formulated in the descriptions of self and other which are involved in the institutions and practices of that society'. Examples of these include decision-making by majority vote, the institution of hiring employees on the basis of free contractual arrangements, the nationalistic basis of international relations and conceptions of the family as the core unit of social institutions.

\section{Decolonisation: A legitimate project for all sciences?}

What, then, is the methodological justification of decolonised knowledge? In terms of the analysis provided by Habermas and Taylor, I would conclude that knowledge imparted purely on the basis of the technical interest holds little promise of a decolonialist transformation. When we are in search of the basic components and structure of physical reality or of the regularities that govern the behaviour of the natural world - including the world of cells, genes, tumours and other bodily tissue (as these feature prominently in aspects of the biomedical sciences) - it is relatively immaterial whether we approach it from a perspective drawn from the West or from a decolonialist context. Nature does not behave differently in Michigan, Russia, Brazil or Zambia. The second law of thermodynamics or the equations of Einsteinian relativity apply everywhere. The value of $x$ in the quadratic formula $\left\{a x^{2}+b x+c=0\right\}$ does not differ for inhabitants of ancient Greece, 18th century France or current-day Zimbabwe. A decolonialist revision of this type of science does not seemingly hold much promise.

The matter, however, is starkly different when we talk about scientific research that springs from both the practical and the emancipatory interests. The social theories that we develop and in terms of which we seek a consensus on what kind of life we ought to pursue and lead, as well as on which values are the best to inspire our choices, are (sometimes deeply) influenced by the social, political and historical contexts in which we live. For example, our understanding of a basic moral requirement such as informed consent in biomedical research can and must be evaluated in terms of the values and histories of the people who we are dealing with, and not in terms of some abstract theory that allegedly applies equally in all circumstances.

Compare the important work (led by Roux ${ }^{[12]}$ ) at the beginning of this century to obtain informed consent from low-income, pregnant women about their HIV status. What worked for these pregnant women (i.e. first informing their mothers, and utilising the influence and status of the latter to deal with the rest of the families), worked well because of the fact that the project had a specific social situatedness in Roux's clinic at Red Cross War Memorial Children's Hospital in Cape Town, South Africa, where it was implemented. ${ }^{[13]}$ It is not self-evident that the same methodology would have been successful for pregnant research subjects in, for example, a rural setting; context played a central role in the success of the project.

It is therefore not for nothing that Charles Taylor persuasively argues that the testing of social theories, in contrast with theories about the natural world, is only possible in terms of establishing the kind of practice that these theories yield or facilitate. ${ }^{[11]} \mathrm{We}$ test social theories - theories emanating from the practical and emancipatory interests - by putting them into practice, i.e. by observing or creatively imagining the kind of social practice that their applications have yielded or are bound to yield. ${ }^{[14]}$ In this sense, historical context is key for the establishment of the validity of social theories. Colonisation is a pivotal part of the historical experience and context of Africans, particularly over the past four centuries, and has been fraught with exploitation, discrimination and racism. When we try to imagine and theorise about a social reality emancipated from the shackles of these memories, decolonisation demonstrates itself as a most worthy intellectual and social ideal - one that rightfully ought to also be pursued in the context of academic research, teaching and social-impact programmes.

A decolonised world requires an emancipated practice emancipated from the shackles of colonialist exploitation over centuries. Research and knowledge that are sought in terms of the practical and emancipatory interests are therefore enterprises that can indeed be decolonised and indigenised for a world that has moved beyond the imperial hold of Western science.

\section{Implications for biomedical sciences}

My conclusion therefore is that the decolonisation of research, particularly in the critical-social (or human) ${ }^{[11]}$ sciences is not only possible but necessary. This leaves the question as to what this implication holds for the biomedical sciences. By 'biomedical sciences' I refer to the range of inquiries or problematics that occur in the curricula of healthcare training and research facilities.

Some of the remarks made earlier about the relevance of decolonisation for the empirical-analytical (popularly called natural) sciences are applicable in this regard. Some biomedical sciences are based on little more than the empirically observable patterns or regularities of physical objects, e.g. cells, tissue, bone, tumours, etc. At the same time, we also know that the human body, which is the 'object' of biomedical research, is hardly adequately understood or treated in terms of descriptions that are exclusively drawn from the natural sciences.

The human body is so much more than merely the externally observable 'thing among things' (res extensa) of which Descartes wrote, and which is mysteriously infused by the alleged thinking 'soul' or res cogitans. ${ }^{[15]}$ The body, so we learn from the work of Maurice Merleau-Ponty, ${ }^{[16]}$ is never a mere 'thing among things'. The body is 'lived through'. It is on the one hand made up of most of the elements in the universe; aspects of it can therefore be observed, known and predicted in a way that is not socially influenced or determined. Yet the body is at the same time a centre of subjectivity - a reference point in terms of which meaning is established and sense is made. The body expresses itself in personhood. The human person is a conscious, highly complex, psychosomatic unity whose functions and wellbeing are conditioned by far more than physical processes and regularities.

A holistic practice of medicine which takes all these aspects into consideration, is, for its optimal efficacy, dependent on biomedical research that is able to identify, locate and analyse the body and to create treatments for its ailments in a way that recognises and respects the complexity referred to in the previous paragraph. It cannot be denied that the wholeness of the person that is researched 
in biomedical sciences is also a function of the social embeddedness of individuals and groups - a social embeddedness that is far from immune from the shackles that phenomena such as colonisation impose on historical agents and communities. To give just one example: nothing of the causes of Steve Biko's death in 1977 can be understood without reference to the oppressive colonial context in which he found himself. ${ }^{[17]}$ But his death is a very dramatic, self-evident example. That same colonial context contributed and continues to contribute as dramatically to the sickness and death of thousands of malnourished children, and of non-identified or under-treated people living with malaria, tuberculosis or HIV/AIDS. Research in the biomedical sciences is therefore as much in need of decolonisation as in any of the critical-social sciences.

Acknowledgements. None.

Author contributions. Sole author.

Funding. None.

Conflicts of interest. None.

1. Chiumbu S. Why decolonise research methods? Some initial thoughts. Presentation at Human Sciences Research Council seminar, 2 May 2017. http://www.hsrc.ac.za/en/research-data/ktree-doc/18320 (accessed 18 May 2018).

2. Rossouw HW. Universiteit, Wetenskap en Kultuur. Cape Town: Tafelberg, 1993.

3. Van Niekerk AA. Rasionaliteit en Relativisme. Pretoria: HSRC, 1992.

4. Mbembe A. Decolonising the university. Arts Hum Higher Edu 2016;15(1):29-45. https://doi.org/10.1177/1474022215618513
5. Kuhn TS. The Structure of Scientific Revolutions. 2nd edition. Chicago: University of Chicago Press, 1970

6. Lakatos I. Falsification and the methodology of scientific research programmes. In: Lakatos I, Musgrave A, eds. Criticism and the Growth of Knowledge. Cambridge: Cambridge University Press, 1982.

7. Feyerabend P. Science in a Free Society. London: Verso Editions, 1978.

8. Kriel J. Matter, Mind and Medicine:Transforming the Clinical Method. Amsterdam: Rodopi, 2000.

9. Bloor D. A Social Theory of Knowledge. London: Macmillan, 1983.

10. Habermas J. Knowledge and Human Interests. 2nd edition. London: Heinemann 1972.

11. Taylor C. Philosophy and the Human Sciences. Cambridge: Cambridge University Press, 1985.

12. Roux P. Informed consent for voluntary counselling and testing for HIV infection in South African mothers and children: An assessment of burdens and consequences and an argument for a modification in the process of informed consent. MPhil (Bioethics) dissertation. Cape Town: University of Cape Town, 2001.

13. Van Niekerk AA. Mother-to-child transmission of HIV/AIDS in Africa: Ethical problems and perspectives. In: Van Niekerk AA, Kopelman LM. Ethics and Aids in Africa: The Challenge to our Thinking. London: Routledge, 2016.

14. Van Niekerk AA. Testing social theories: Validation, practice and reality. In: Schröter J, ed. Konstruktion von Wirklichkeit: Geschichte als Sinnbildung und die Anfänge des Christentums. Berlin: Walter de Gruyter, 2004.

15. Descartes R. [Discourse on Method and the Meditations] translated Sutcliffe TFE. Harmondsworth: Penguin Books, 1968.

16. Merleau-Ponty M. Phenomenology of Perception. London: Routledge \& Kegan Paul, 1962.

17. Van Niekerk AA, Benatar SR. The social functions of bioethics in South Africa. In: Myser C, ed. Bioethics around the Globe. Oxford: Oxford University Press, 2011.

Accepted 5 November 2018 